\title{
An Old Drug for a New Application: Potential Benefits of Sildenafil in Wound Healing
}

\author{
Shadi Farsaei, Hossein Khalili, Iman Karimzadeh, Simin Dashti-Khavidaki. \\ Department of Clinical Pharmacy, Faculty of Pharmacy, Tehran University of Medical Sciences, Tehran, Iran.
}

Received, May 4, 2012; Revised, July 17, 2012; Accepted, August 9, 2012; Published, August 12, 2012.

\begin{abstract}
Purpose: Several studies have evaluated the effects of sildenafil on the tissue repair and wound healing. In the present review, the impact of sildenafil on the wound healing in all available clinical and nonclinical (experimental) studies has been discussed. Methods: A literature search was performed using PubMed, Scopus, Medline, Embase, Cochrane central register of controlled trials and Cochrane database systematic reviews. Related articles indexed in Google Scholar were also included. Key words used as search terms were 'phosphodiesterase inhibitor', 'sildenafil', 'skin', 'cutaneous', 'skin lesion', 'skin damage', 'wound', and 'wound healing'. No time limitation was considered in this review. Results: A total of 15 animal studies, 7 case reports, and 2 small clinical studies have reported the effects of sildenafil on the wound healing. The effects included skin flaps and grafts, anastomosis, systemic sclerosis and Raynaud's disease. Conclusions: The available data support the beneficial effects of sildenafil in improvement of tissue healing in various conditions.
\end{abstract}

This article is open to POST-PUBLICATION REVIEW. Registered readers (see "For Readers") may comment by clicking on ABSTRACT on the issue's contents page.

\section{INTRODUCTION}

Healing of the chronic wounds remains a challenging problem $(1,2)$. Tissue injury triggers a cascade of repair events designed to restore tissue integrity and function (3). The wound healing process begins with hemostasis, and various inflammatory cells such as polymorphonuclear cells and macrophages play a key role in this early stage of wound healing $(4,5)$. In the next stage, keratinocytes migrate to the wound site to initiate tissue re-epithelization and granulation (6). Other critical events in the tissue repair process are remodeling and angiogenesis, which are necessary for restoration of blood flow and oxygen supply to the tissue (7).

Beneficial effects of nitric oxide (NO) have been shown in wound healing, including potentiation of the clotting process (8), scavenging of oxidative stress components (5), improvement of angiogenesis (9), promotion of endothelial cell proliferation $(10,11)$, and tissue remodeling (12). Roles for NO in the regulation of vasodilation (13), control of the cell cycling and apoptosis (14), cell proliferation and differentiation (15), enhancement of oxygen delivery (16), and even antimicrobial activity (17) have been described in previous studies. These biological activities of NO have resulted in its introduction as a wound healing biomarker (18).

Topical NO-releasing formulations have shown clinically significant vasodilation in the localized systemic sclerosis (19) and Raynaud's disease (20). Poor wound healing has been associated with deficiencies in inducible NO synthase (iNOS) and endothelial NOS (eNOS) (21-24), whereas a topical NO donor and a precursor of NO such as L-arginine both improved the wound healing process in diabetic mice (25-26).

Sildenafil, an agent that sustains the cGMPenhancing effect of NO, was initially developed as an antihypertensive agent (27). Due to the unexpected side effect of promotion of penile erection, in 1998, sildenafil citrate (Viagra, Pfizer) became the first phosphodiesterase type 5 (PDE5) inhibitor on the market for the treatment of erectile dysfunction (28). More than 750,000 prescriptions were filled during the first 7 years of its introduction (29-32).

Correspondening Author: Hossein Khalili, Department of Clinical Pharmacy, Faculty of pharmacy, Tehran University of Medical Sciences, Tehran, Iran; Email khalilih@tums.ac.ir 
Since then, sildenafil has shown benefits in experimental stroke models $(33,34)$. These properties, together with the effects on the cardiovascular system $(35,36)$, have prompted further research on the potential beneficial effects of sildenafil in treatment of neurological conditions and injuries that affect vascular perfusion. Clinical studies support the use of sildenafil as a treatment for various forms of pulmonary arterial hypertension in both children and adults $(37,38)$, and for prevention or management of right heart failure $(39,40)$. The observation of an antiplatelet effect of sildenafil and its influence in improving the microcirculation during wound healing in animal and human studies has also been encouraging (41-43).

Other animal and clinical studies have demonstrated potential benefits of sildenafil in conditions associated with diminished skin blood flow and poor vascularization, such as Raynaud's phenomenon and digital ulcers in patients with systemic sclerosis (44-47). Different studies have shown beneficial effects of low doses of sildenafil on portopulmonary hypertension following liver transplantation (48), or on systemic sclerosis associated with pulmonary hypertension (49). It seems that sildenafil exerts its beneficial actions on the process of wound healing through different mechanisms that include vasodilation (4), enhanced microcirculatory hemodynamics through inhibition of platelet aggregation and adhesion (50), stimulation of angiogenesis (51), induction of apoptosis of adhesion fibroblasts, and reduction of inflammatory responses (3). Data from animal models on the beneficial effects of sildenafil on wound healing are promising but human data are currently lacking (52).

Several research studies have been focused on different effects of sildenafil on tissue repair. In the present review, the impact of sildenafil on wound healing in all clinical and non-clinical (experimental) studies is discussed.

\section{METHODS}

A literature search was performed using PubMed, Scopus, Medline, Embase, the Cochrane central register of controlled trials, and the Cochrane database systematic reviews. Related articles indexed in Google Scholar were also included. Key words used as search terms were 'phospho- diesterase inhibitor', 'sildenafil', 'skin', 'cutaneous', 'skin lesion', 'skin damage', 'wound', and 'wound healing'. No time limitation was considered in this review. Only English-language articles were considered eligible for inclusion. Two case reports written in German and Spanish were excluded. All studies (experimental, quasiexperimental, and clinical), which evaluated the effect of sildenafil on wound healing as a main endpoint, were included. Improved wound-healing processes with sildenafil were suggested in different animal $(3,4,41,42,50,51,53-61)$ and human studies $(45,47,62-67)$.

\section{RESULTS}

\section{Experimental studies that have evaluated sildenafil effects in wound healing}

Sildenafil has been actively investigated in wound healing, mainly with respect to maintenance of skin flap viability (Table 1).

\section{Effect of sildenafil on skin flap survival}

Flap necrosis remains a challenging issue following plastic and reconstructive surgeries (68). Partial or complete necrosis of a flap can lead to detrimental consequences including wound dehiscence, delayed wound healing, wound contracture, infection, and fistula formation $(69,70)$. Arterial insufficiency and venous congestion play major roles in flap necrosis. Several factors could contribute to arterial insufficiency, such as release of vasoactive agents as well as oxygen-derived free radicals, and formation of thrombosis in arteries and/or veins (71). Based on these mechanisms, numerous pharmacological modalities, ranging from sympatholytics, vasodilators, calcium channel blockers, and prostaglandin inhibitors to anticoagulants, glucocorticoids, and free radical scavengers, have been studied for potential improvement in flap survival but have met with various degrees of success $(72,73)$. Because of their vasodilating, angiogenic, and decreased platelet aggregation properties, the PDE inhibitors such as sildenafil have now been examined in several experimental studies for possible beneficial effects of on the viability of skin flaps. 


\begin{tabular}{|c|c|c|c|c|c|}
\hline Study & Subjects (Number) & Intervention group & $\begin{array}{l}\text { Control } \\
\text { group }\end{array}$ & $\begin{array}{c}\text { Duration of } \\
\text { sildenafil treatment }\end{array}$ & Main result(s) \\
\hline $\begin{array}{l}\text { Sarifaki } \\
\text { oglu et } \\
\text { al. }(42)\end{array}$ & $\begin{array}{l}\text { Rats with caudally } \\
\text { based skin flaps (32) }\end{array}$ & $\begin{array}{l}\text { Received } 3,10 \text {, or } 20 \mathrm{mg} / \mathrm{kg} / \text { day sildenafil } \\
\text { solution orally }\end{array}$ & $\begin{array}{l}\text { Received } 56 \\
\text { m1/day tap } \\
\text { water orally }\end{array}$ & 7 days & $\begin{array}{l}\text { Orally administered sildenafil } \\
\text { improved the survival of skin } \\
\text { flaps in a dose-dependent } \\
\text { manner }\end{array}$ \\
\hline $\begin{array}{l}\text { Ulusoy } \\
\text { et al. } \\
(41)\end{array}$ & $\begin{array}{l}\text { Rats with caudally } \\
\text { based skin flaps } \\
(50)\end{array}$ & $\begin{array}{l}\text { Group II: Silastic sheet separated the flap } \\
\text { from the underlying vascular bed once } \\
\text { Group III: } 0.5 \mathrm{ml} \text { fibrin glue was placed to } \\
\text { under-flap once } \\
\text { Group IV: } 2.5 \mathrm{mg} \text { sildenafil mixed in } 0.5 \\
\text { ml of fibrin glue was placed to under-flap } \\
\text { once } \\
\text { Group V: } 10 \mathrm{mg} \text { sildenafil mixed in } 0.5 \\
\text { ml of fibrin glue was placed to under-flap } \\
\text { once }\end{array}$ & $\begin{array}{l}\text { Group I: } \\
\text { Received no } \\
\text { treatment }\end{array}$ & $\begin{array}{l}\text { (Combination was } \\
\text { placed under-flap for) } \\
7 \text { days }\end{array}$ & $\begin{array}{l}\text { Topically administered } \\
\text { sildenafil combined with fibrin } \\
\text { glue improved skin flap } \\
\text { viability and vascular density } \\
\text { in a dose-dependent manner }\end{array}$ \\
\hline $\begin{array}{l}\text { Ayyildi } \\
\text { z et al. } \\
(54)\end{array}$ & $\begin{array}{l}\text { Full-thickness tubed } \\
\text { free skin grafts in rats } \\
\text { (15) }\end{array}$ & $\begin{array}{l}0.5 \mathrm{mg} / \mathrm{kg} / \mathrm{day} \text { sildenafil solution (study } \\
\text { group) or } 1 \mathrm{ml} / \mathrm{kg} / \text { day saline solution } \\
\text { (sham group) was administered topically }\end{array}$ & $\begin{array}{l}\text { Received no } \\
\text { treatment }\end{array}$ & 7 days & $\begin{array}{l}\text { Topically administered } \\
\text { sildenafil was not effective in } \\
\text { the achievement and } \\
\text { preservation of full-thickness } \\
\text { tubed free skin grafts viability }\end{array}$ \\
\hline $\begin{array}{l}\text { Hart et } \\
\text { al. (51) }\end{array}$ & $\begin{array}{l}\text { Rats with caudally } \\
\text { based skin flaps } \\
(109)\end{array}$ & $\begin{array}{l}9 \mathrm{mg} / \mathrm{kg} / \text { day sildenafil solution (treatment } \\
\text { group) or } 0.05 \mathrm{~N} \text { hydrochloric acid in } 5 \\
\text { ml saline (vehicle control group) was } \\
\text { administered intraperitoneally }\end{array}$ & $\begin{array}{l}\text { Received no } \\
\text { treatment } \\
\text { (sham group) }\end{array}$ & 7 days & $\begin{array}{l}\text { Intraperitoneally administered } \\
\text { sildenafil decreased areas of } \\
\text { necrosis of skin flaps } \\
\text { Improvement in skin flap } \\
\text { viability was greater at the } \\
\text { earlier postoperative time } \\
\text { points than later ones }\end{array}$ \\
\hline $\begin{array}{l}\text { Barral et } \\
\text { al. (59) }\end{array}$ & $\begin{array}{l}\text { Rats with caudally } \\
\text { based skin flaps } \\
(20)\end{array}$ & $\begin{array}{l}\text { Received } 0.5 \mathrm{mg} / \mathrm{kg} / \text { day sildenafil } \\
\text { solution subdermally }\end{array}$ & $\begin{array}{l}\text { Received } 5 \\
\mathrm{ml} / \mathrm{kg} / \text { day } \\
\text { saline solution } \\
0.9 \% \\
\text { subdermally }\end{array}$ & 2 days & $\begin{array}{l}\text { Subdermally administered } \\
\text { sildenafil decreased viability } \\
\text { of skin flaps }\end{array}$ \\
\hline $\begin{array}{l}\text { Uzun et } \\
\text { al. (58) }\end{array}$ & $\begin{array}{l}\text { Rats with normal or } \\
\text { ischemic colon } \\
\text { anastomosis } \\
(56)\end{array}$ & $\begin{array}{l}\text { Received } 10 \mathrm{mg} / \mathrm{kg} / \mathrm{day} \text { sildenafil solution } \\
\text { orally (normal or ischemic anastomosis) }\end{array}$ & $\begin{array}{l}\text { Received no } \\
\text { treatment } \\
\text { (normal or } \\
\text { ischemic } \\
\text { anastomosis) }\end{array}$ & $\begin{array}{l}3 \text { days for (in) } 7 \text { rats } \\
\text { with normal or } \\
\text { ischemic colon } \\
\text { anastomosis } \\
7 \text { days for (in) } 7 \text { rats } \\
\text { with normal or } \\
\text { ischemic colon } \\
\text { anastomosis }\end{array}$ & $\begin{array}{l}\text { Orally administered sildenafil } \\
\text { enhanced the healing process } \\
\text { of colonic anastomotic wound }\end{array}$ \\
\hline $\begin{array}{l}\text { Irkorucu } \\
\text { et al. } \\
(55)\end{array}$ & $\begin{array}{l}\text { Rats with ischemic } \\
\text { colitis } \\
(28)\end{array}$ & $\begin{array}{l}10 \mathrm{mg} / \mathrm{kg} / \text { day sildenafil solution } \\
\text { (treatment group) or tap water (sham- } \\
\text { operated) was administered orally }\end{array}$ & $\begin{array}{l}\text { Received tap } \\
\text { water orally }\end{array}$ & 3 days & $\begin{array}{l}\text { Orally administered sildenafil } \\
\text { improved ischemic colitis }\end{array}$ \\
\hline $\begin{array}{l}\text { Irkorucu } \\
\text { et al. } \\
\text { (57) }\end{array}$ & $\begin{array}{l}\text { Rats with normal or } \\
\text { ischemic left colon } \\
\text { anastomosis }\end{array}$ & $\begin{array}{l}10 \text { or } 20 \mathrm{mg} / \mathrm{kg} / \text { day sildenafil solution or } \\
\text { tap water was administered orally } \\
\text { (ischemic left colon anastomosis) }\end{array}$ & $\begin{array}{l}\text { Received tap } \\
\text { water orally } \\
\text { (normal left }\end{array}$ & 4 days & $\begin{array}{l}10 \mathrm{mg} / \mathrm{kg} \text { sildenafil } \\
\text { administered orally enhanced } \\
\text { the healing process of left }\end{array}$ \\
\hline
\end{tabular}


(36)

\begin{tabular}{|c|c|}
\hline & (36) \\
\hline $\begin{array}{l}\text { Batukan } \\
\text { et al. } \\
(56)\end{array}$ & $\begin{array}{l}\text { Rats with } \\
\text { postoperative intra- } \\
\text { abdominal adhesion } \\
(32)\end{array}$ \\
\hline $\begin{array}{l}\text { Ayten et } \\
\text { al. (60) }\end{array}$ & $\begin{array}{l}\text { Rats with left colon } \\
\text { anastomosis, intra- } \\
\text { abdominal adhesion, } \\
\text { and infection } \\
\text { (14) }\end{array}$ \\
\hline $\begin{array}{l}\text { Tas et } \\
\text { al. (3) }\end{array}$ & $\begin{array}{l}\text { Dogs with open } \\
\text { wounds on anterior } \\
\text { brachial region } \\
\text { (16) }\end{array}$ \\
\hline $\begin{array}{l}\text { Derici et } \\
\text { al. (4) }\end{array}$ & $\begin{array}{l}\text { Rats with abdominal } \\
\text { fascia wall wound } \\
(100)\end{array}$ \\
\hline $\begin{array}{l}\text { Jamshid } \\
\text { zadeh et } \\
\text { al. (61) }\end{array}$ & $\begin{array}{l}\text { Rats with wound at } \\
\text { panniculuscarnosus } \\
\text { and adherent tissues } \\
\text { (30) }\end{array}$ \\
\hline
\end{tabular}

\author{
Received $3.75,7.5$, or $15 \mathrm{mg} / \mathrm{kg} /$ day $\quad$ Received tap 5 days \\ sildenafil solution orally \\ water orally \\ Received $8 \mathrm{mg} / \mathrm{kg} /$ day sildenafil solution \\ intraperitoneally
}

Received 25 mg sildenafil solution orally

Received

saline solution

orally

Received $10 \mathrm{mg} / \mathrm{kg} / \mathrm{day}$ sildenafil solution
orally

Received no

treatment

(standard

laboratory

diet)

Received 25 mg/day sildenafil topically

Received the same cream

base colonic anastomotic wound

Anti-inflammatory effects of sildenafil on left colonic anastomotic wound was dosedependent

Orally administered sildenafil attenuated postoperative intraabdominal adhesion formation

Intraperitoneally administered sildenafil improved anastomotic healing of the left colon and reduced peritoneal adhesion formation in the presence of intra-abdominal infection

Days $1,3,5$, and 7 post operative

Orally administered sildenafil enhanced the process of wound healing

10 days (before surgery)

Orally administered sildenafil enhanced wound healing of the abdominal fascia wall

Topically administered sildenafil augmented the wound healing process
Sarifakioglu et al. used a rat model to conduct the first experimental study to evaluate the potential effects of sildenafil on survival of skin flaps. A skin flap was designed on the dorsum of 32 rats, and then they were randomly divided into 4 equal groups, including 1 control (control rats received tap water orally) and 3 treatment groups (rats received 3,10 , or $20 \mathrm{mg} / \mathrm{kg} /$ day of sildenafil solution orally). Administration of the drug or tap water was initiated 2 hours after the surgical procedure and was continued for 7 days. During the study period, flaps were photographed and the surviving areas of the skin flaps in each group were determined using a planimeter. The mean percentage of survival of flaps in the group that received sildenafil at dose of $20 \mathrm{mg} / \mathrm{kg} / \mathrm{day}$ was significantly higher than the survival percentages of the other groups $(\mathrm{P}<0.01)$. These data suggested that sildenafil could improve the survival of skin flaps in a dose-dependent manner. The authors proposed that the beneficial effects of sildenafil on skin flap viability might be independent of the NO/cGMP pathway and could be explained by improvement in microcirculatory hemodynamics (42).

Ulusoy et al. investigated the efficacy of sildenafil, combined with fibrin glue, on flap survival in rats with the aim of achieving sitespecific delivery, prolonging exposure to action site, and minimizing systemic side effects. Fifty rats were randomly assigned to 5 groups of 10 rats each. The first group was a control; the second group received no pharmacologic treatment, but a thin silastic sheet was placed to separate the flap from the underlying vascular bed. The third group received $0.5 \mathrm{ml}$ of fibrin glue to the flap site, while the donor site of the flap in the fourth and fifth groups was treated with different doses of sildenafil ( 2.5 and $10 \mathrm{mg}$, respectively) mixed in $0.5 \mathrm{ml}$ of fibrin glue. On postoperative day 7 , the flap dimensions were digitally photographed and histological examinations were performed. Mean flap survival areas in sildenafil groups were significantly higher than in the control groups $(\mathrm{P}<$ 0.0001). In addition, the decrease in skin flap necrosis was statistically larger in the group treated with $10 \mathrm{mg}$ of sildenafil than in the group treated 
with $2.5 \mathrm{mg}$ of sildenafil group. In accordance with the increased area of survival, histological examination showed significantly higher vascular density in sildenafil-treated groups than in the control groups $(\mathrm{P}<0.0001)$. These findings demonstrated that under-flap application of sildenafil mixed with fibrin glue could improve flap survival in a dose-dependent manner by maintaining high drug concentration in the site of injury (41).

Ayyildiz et al. were the first to evaluate the possible effects of locally-injected sildenafil on the viability of flaps in rats and to compare it with orally (enterally) administered sildenafil. The extent of flap necrosis was significantly lower in the groups treated with local injection $(\mathrm{n}=10)$ and oral sildenafil $(\mathrm{n}=10)$ than in the controls $(\mathrm{n}=10)(\mathrm{P}<$ $0.0001)$. Interestingly, the necrosis area was significantly smaller in the parenteral sildenafil $(0.5$ $\mathrm{mg} / \mathrm{kg} /$ day for 7 days) group in the groups given enteral sildenafil (1 $\mathrm{mg} / \mathrm{kg} / \mathrm{day}$ for 7 days). Histopathological evaluation of stained flap specimens revealed minimal inflammation, no necrotic areas, apparent fibroblast proliferation, and macrophage infiltration in the locally-injected sildenafil group. According to these findings, locally-injected sildenafil was more effective than oral administration in improving the viability of flaps. The antiplatelet aggregation and vasodilatory effects of sildenafil may explain its actions in enhancing survival of skin flaps (50).

Hart et al. examined the short- and long-term beneficial effects of intraperitoneally administered sildenafil ( $9 \mathrm{mg} / \mathrm{kg} /$ day for 1 week) on rat skin flap viability. Rats were assigned to 3 groups: sildenafiltreated $(\mathrm{n}=34)$, vehicle control $(\mathrm{n}=35)$, and sham (no injection; $\mathrm{n}=40$ ). The first intraperitoneal injection was performed immediately after creating flaps. The extent of vascularity, vessel stasis, and blood flow in skin flaps were assessed by digital photography analysis for each group on postoperative days $1,3,5$, and 7 . The imaging results revealed that the zones of necrosis and stasis on days 1 and 3 decreased in size significantly in the rats treated with sildenafil compared with the controls $(\mathrm{P}<0.05)$. Interestingly, a significant decrease in necrosis zones was detected between sildenafil-treated and control rats throughout the study $(\mathrm{P}<0.05)$. Furthermore, a greater reduction in size of both the necrotic and the total affected areas was observed in the sildenafil-treated rats at days 1 and 3 than later, on days 5 and 7. The reduction in skin flap necrosis in this study (about $24 \%$ ) was lower than that reported in the Sarifakioglu et al. survey (41\%). This difference may be related to variations in experimental design, such as administration route and dose of sildenafil, as well as the method of determining zones of skin flap necrosis. The further decrease in flap necrosis at the earlier postoperative periods (days 1 and 3) could be attributed to greater vasodilatory effects of sildenafil at the early stages. At later stages (days 5 and 7), sildenafil angiogenic effects might predominate (51).

Decreases in the beneficial effects of sildenafil on skin flap viability in the later postoperative phases of were also reported by Hart et al. They suggested that sildenafil alone may not be sufficient for long-term maintenance of flap viability and that an additional pharmacologic intervention, such as angiogenic factors, may be necessary. Therefore, Tsai et al. examined the hypothesis that combination therapy with sildenafil as a vasodilator and vascular endothelium growth factor (VEGF) as an angiogenic factor would improve skin flap viability more than either therapy alone. For the evaluation of the therapeutic efficacy, 123 rats were divided into sildenafil $(\mathrm{n}=24)$, VEGF $(\mathrm{n}=23)$, combination of sildenafil and VEGF $(n=21)$, vehicle $(n=24)$, and control $(n=31)$ groups. Rats assigned to the sildenafil group received intraperitoneal injections of sildenafil (10 $\mathrm{mg} / \mathrm{kg} /$ day) immediately after flap surgery and then every $24 \mathrm{hrs}$ for 7 days. Rats in the VEGF group were given a dose of 4 mcg VEGF sub-dermally once, prior to flap closure. The sildenafil and VEGF combination treatment group received sildenafil and VEGF administered in the same manner as in the sildenafil and VEGF groups. Avascularity, vascular stasis, and normal capillary blood flow zones were determined by imaging. Imaging analysis demonstrated a significant reduction in avascular and stasis areas in the combined sildenafil and VEGF treatment compared to the control group at 7 days post-surgery $(\mathrm{P}<0.05)$; however, the combination-treated group did not differ significantly from the sildenafil-treated group at 7 days post operation. Histological analysis showed no statistically significant differences in vessel density between the groups. The failure of combination therapy to show any further benefits compared to sildenafil alone could be partially due 
to insufficient VEGF dosage for inducing an angiogenic effect. Furthermore, rapid and short release of VEGF at the injection site may lead to vasodilation and subsequent lowering of the perfusion pressure in the ischemic areas of the skin flaps. Development of slow-release VEGF formulations to prolong delivery time and provide lower concentrations of the drug for a longer period may counteract the early detrimental effects of VEGF and improve late skin flap survival (53).

The most recent and challenging study regarding the possible actions of sildenafil in viability of skin flaps was conducted in 2011by an investigational team from Brazil. Twenty rats were divided equally into a study and a control group. The sildenafil solution $(0.5 \mathrm{mg} / \mathrm{kg} /$ day $)$ was fractionated and administered sub-dermally to 9 points of the flap. The first administration was performed immediately after the surgical procedure and continued for 48 hours. On postoperative day 7 , the flaps were photographed. The mean necrotic areas were significantly higher in the study group than in the control group $(\mathrm{P}=0.003)$. Viability area of the skin flap was lower in the study group than in the control group; however, this difference was not statistically significant. Granulation with and without polymorphonuclear cell infiltration, and granulation with necrosis did not differ significantly between the study and control groups. The authors recommended further experimental studies to elucidate a precise role for sildenafil on viability of skin flaps (59).

\section{Effect of sildenafil on skin graft viability}

Following a successful outcome of application of topical sildenafil on flap viability, Ayyildiz et al. (50) analyzed the possible effectiveness of topically administered sildenafil on the viability of fullthickness tubed skin grafts in rats. Fifteen rats were randomly allocated to 3 groups: control, sham, and study. A full-thickness tubed free skin graft was prepared from the skin tissue of the abdominal region of each rat. A silicone feeding tube with a number of small holes was inserted. The graft was located in such a way on another portion of the abdomen that a part of the feeding tube was left exposed. Histopathological features were similar in the study group $(0.5 \mathrm{mg} / \mathrm{kg} /$ day of sildenafil given by a catheter for 1 week) and the control groups. Although formation of new vessels was detected in the study group, the mean vascular density did not differ significantly between the two groups. These findings were not as encouraging as the results observed with the flaps in the previous studies. The authors concluded that topically administered sildenafil was not effective for achieving and maintaining the viability of full-thickness tubed free skin grafts in rats (54).

\section{Effect of sildenafil on ischemic colon anastomosis and colitis}

Colon anastomosis is one of the most common surgeries performed today. Despite substantial improvement in the surgical techniques, anastomotic leakage remains a major clinical problem that can lead to increased patient mortality and morbidity. The prevalence of intraperitoneal anastomotic leakage is reported to be between $0.5 \%$ and $30 \%(74,75)$. Similar to what is observed with skin flap necrosis, many factors contribute to the impairment of anastomotic healing, such as release of vasoactive agents and oxygen-derived free radicals (76). Treatment of anastomotic leakage remains relegated to supportive care, and no specific therapy has yet been approved for it.

Based on its known pharmacological properties, several studies investigated the potential benefits of sildenafil on experimental models of ischemic colon anastomosis. A survey by Uzun et al. examined the effects of sildenafil on normal and ischemic colon anastomosis in a rat model. Fifty-six rats were randomly allocated to 4 equal groups $(\mathrm{n}=14)$ : normal anastomosis, ischemic anastomosis, and normal and ischemic anastomosis treated with sildenafil. A standard model of end-to-end anastomosis of the left colon was used. Ischemic colon anastomosis was developed by ligating the whole vessels in the mesocolon. Sildenafil at a dose of $10 \mathrm{mg} / \mathrm{kg} /$ day was administered orally to the treatment groups. Seven out of 14 rats with normal or ischemic colon anastomosis were sacrificed on postoperative day 3 and the others on postoperative day 7. Levels of NO, thiobarbituric acid reactive substrates (as a marker of lipid oxidation), and glutathione (as an antioxidant) in blood and colonic tissues were measured in this study. The sildenafiltreated groups (both normal and ischemic anastomotic) had significantly higher tissue NO than control groups at postoperative day $3(\mathrm{P}<$ $0.05)$. The amount of glutathione in the erythrocytes (but not in the tissue) was significantly elevated in the ischemic anastomosis group following sildenafil 
administration. Tissue thiobarbituric acid reactive substrates were elevated in the rats with normal anastomosis following sildenafil therapy at postoperative days $3(\mathrm{P}<0.001)$ and $7(\mathrm{P}<0.05)$. Furthermore, no statistically significant differences in tissue and blood levels of the parameters were observed between postoperative days 3 and 7 in either the normal or ischemic anastomosis groups that received sildenafil. The results of the study suggested a beneficial effect of sildenafil on the healing of anastomotic wounds through alteration of NO metabolism and lipid peroxidation. In addition, wound healing following sildenafil administration was more considerable in the ischemic than in the normal anastomosis, indicating additional beneficial effects of sildenafil on the ischemic wound (58).

Another study provided the first investigation of the potential benefits of sildenafil on an experimental model of ischemic colitis. Twentyeight rats were randomized in 3 groups; 8 rats were sham-operated and received tap water, whereas ischemic colitis was induced by surgery in the treatment and control groups. The treatment group received $10 \mathrm{mg} / \mathrm{kg} /$ day of sildenafil through an orogastric tube for 3 days, while the control group received only tap water. When compared to the ischemic colitis group that received tap water, the group treated with sildenafil showed significantly decreased areas of ischemic changes $(\mathrm{P}=0.0001)$, macroscopically visible mean damage scores $(\mathrm{P}=$ $0.0001)$, and severity of ischemia $(\mathrm{P}=0.017)$. Improvements in vascular smooth muscle function and microcirculatory hemodynamics were considered to be the main beneficial effects of sildenafil on the ischemic colon tissues (55).

The potential benefits of sildenafil on the healing of ischemic colon anastomosis were investigated in another experimental rat model (57). Thirty-six male rats were randomized into four equal groups. Colonic bowel segments of the rats in group 1 were transected, and the free ends were anastomosed. Animals in groups 2, 3, and 4 underwent a standard surgical procedure to induce ischemic colon anastomosis. Group 2 received only tap water, while groups 3 and 4 received sildenafil at doses of 10 and $20 \mathrm{mg} / \mathrm{kg} /$ day, respectively via an orogastric tube for 4 days. Rats were sacrificed on the day 4 following the operation. The first drug solution was administered within 2 hours after the operation. Bursting pressure and tissue hydroxyproline level were measured as indicators of collagen synthesis and anastomotic healing indicators, respectively (57). The severity of ischemia and the degree of adhesion in this study were determined based on well-defined criteria (7778). Except in the $20 \mathrm{mg} / \mathrm{kg} /$ day group, the bursting pressure in rats that received $10 \mathrm{mg} / \mathrm{kg}$ /day of sildenafil did not differ significantly from the group with normal colon anastomosis who received tap water $(P=0.237)$. Tissue hydroxyproline levels, adhesion, and severity of ischemia scores also showed no statistically significant differences between the treatment and control groups with ischemic colon anastomosis. The lowest number of inflammatory cells was detected in the granulation tissue in ischemic colon anastomosis rats treated with $20 \mathrm{mg} / \mathrm{kg} / \mathrm{day}$ of sildenafil $(\mathrm{P}=0.0001)$. The failure of sildenafil at a dose of $20 \mathrm{mg} / \mathrm{kg} / \mathrm{day}$ to improve the anastomotic bursting pressures in ischemic colon anastomosis may be due to greater vasodilatory effects and diminished tissue perfusion pressure. Furthermore, the anti-inflammatory effects of sildenafil may be dose-dependent as suggested by the observation that the lowest numbers of inflammatory cells and fibroblast infiltration were observed in rats treated with 20 $\mathrm{mg} / \mathrm{kg} /$ day of sildenafil. The authors conclude that additional investigations are still needed to confirm the optimal administration time and dosage of sildenafil in ischemic colon anastomosis models (57).

The potential benefits of sildenafil on decreasing formation of postoperative intraabdominal adhesions were investigated by Batukan et al. in a rat model. An intra-abdominal adhesion was created in each of 32 rats by electrocauterization of the uterine horn and abrasion of the adjacent parietal peritoneum. Rats in the treatment groups were randomized to receive daily doses of $3.75,7.5$, or $15 \mathrm{mg} / \mathrm{kg}$ of sildenafil enterally one hour before operation and then after surgery for 5 days. The control group received a placebo. The extent and severity of adhesions on postoperative day 14 were determined by the Leach et al. (79) and Knightly et al. (80) criteria, respectively. The severity (but not the extent) of adhesions was significantly lower in the rats treated with $15 \mathrm{mg} / \mathrm{kg} /$ day of sildenafil than in the other groups $(\mathrm{P}<0.05)$. The beneficial effects of sildenafil on reducing the severity of adhesion formation could be explained by decreases in vascular tone and maintenance of adequate tissue 
perfusion to traumatized areas, which would enhance microcirculatory hemodynamics through inhibition of platelet function, and induce apoptosis of adhesion fibroblasts (56).

Ayten et al. entered the debate on successful gastrointestinal anastomosis in the presence of intraperitoneal infection by conducting a pilot study to assess the effects of physiologic doses of sildenafil on intra-abdominal adhesion formation and healing of left colon anastomosis in an intraabdominally infected rat model. Abdominal peritonitis was induced by creating a single puncture in the colon above the pelvic peritoneum. The colonic segment above the pelvic peritoneum was resected and then end-to-end full-thickness anastomosis was performed. The rats were assigned to 2 groups: Group $1(\mathrm{n}=7)$ had intra-abdominal infection, resection, and anastomoses. Group 2 consisted of 7 rats with intra-abdominal infections, resections, anastomoses, which received sildenafil at a dose of $8 \mathrm{mg} / \mathrm{kg}$ for 7 days. A standard scale was used to assess intra-abdominal adhesions and anastomotic bursting pressure was measured in vivo. The tissue hydroxyproline level was determined by the modified Woessner method (81) and histopathological examinations were performed by a modified Ehrlich and Hunt numeric scale (82). In the sildenafil-treated group, intra-abdominal adhesion scores were significantly lower $(\mathrm{P}=0.03)$ and the mean anastomotic bursting pressure was significantly higher than in the control group $(\mathrm{P}=$ 0.02). Although mean tissue hydroxyproline concentrations were higher in the rats that received sildenafil than in control group, the difference was not statistically significant. Increased blood flow in the splanchnic area in response to sildenafil could account for the lower adhesion scores in the treatment compared to control groups. These data support the beneficial effects of sildenafil on the healing of colonic anastomosis as well as in the reduction of peritoneal adhesion formation in the presence of intra-abdominal infection (60).

\section{Effect of sildenafil on skin wound healing}

Tas et al. conducted an in vivo and in vitro experimental study in dogs to evaluate the role of sildenafil in wound healing. In the in vivo study, 16 dogs were randomly divided into 2 equal groups and then round open wounds were created across all skin layers on the anterior brachial region. Experimental and control groups received sildenafil
(25 mg) and saline orally on days 1, 3, 5, and 7 following surgery, respectively. Samples from the wound tissues were dissected on days 3,6 , and 9 after intervention and were assessed histologically. The in vitro study was performed on a segment of the arteria brachialis that was removed from the dogs. Arteria brachialis rings were randomly immersed into sildenafil citrate, acetylcholine, and sodium nitroprusside solutions. Isometric responses were recorded by strain gauge transducers attached to a polygraph. In the in vivo study, dogs that received sildenafil had greater granulosa tissue, more apparent capillary network, and greater fibroblast proliferation when compared to the control group on day 6. In the in vitro study, the vaso-relaxant effects were significantly lower for sildenafil than for acetylcholine and sodium nitroprusside $(\mathrm{P}<0.001)$. Results of this study support the hypothesis that sildenafil could enhance the processes of wound healing, probably through vasodilation and angiogenesis (3).

Jamshidzadeh et al. assessed the hypothesis that topical sildenafil may improve skin wound healing in an animal model. The paniculus carnosus and adherent tissues were removed from 30 rats, which were then were randomly divided into 2 groups: treatment (received $25 \mathrm{mg} /$ day of sildenafil topically) and control (received the same cream base without sildenafil). On post-operative days 7 , 14 , and 21,5 animals from each group were randomly selected and sacrificed (61). The rate of wound healing was calculated by the formula used by Li et al. (83). Histological examinations were performed according to the scoring system described by Qiu et al. (84). In the sildenafil-treated group, the wound area decreased to $15 \%, 26 \%$, and $46 \%$ of the baseline by postoperative days 7,14 , and 21 , respectively $(\mathrm{P}<0.001)$. The treatment group also showed more fibroblast and macrophage migration, increased vascularization, greater collagen regeneration, and more extensive reepithelialization. This animal study showed that sildenafil is effective in skin wound healing (61).

\section{Effect of sildenafil on abdominal wound healing}

The most recent experimental study regarding the potential benefits of sildenafil on the wound healing process was carried out by Derici et al. (4). One hundred rats were randomized into 2 equal groups: control $(\mathrm{n}=50)$ and study $(\mathrm{n}=50)$. The study group received $10 \mathrm{mg} / \mathrm{kg} /$ day of sildenafil orally via 
an orogastric tube for 10 days and then a midline laparotomy was performed. Ten animals from each group were sacrificed at postoperative days $4,7,14$, 21 , and 35 . The breaking strength of the midline incision was determined by a tensiometer, as described by Gulcelik et al. (85). Abdominal incision wound samples were used for pathological and histological examinations as well as for hydroxyproline content measurement. Histological grading was performed by the Abramov scoring system (86). At all times of the study, the breaking strengths of the midline incision of the abdominal fascia were significantly higher in the study than in the control group $(\mathrm{P}<0.05)$. Neovascularization at postoperative days $7,14,21$, and 35 and acute inflammation score on day 14 differed significantly between the study and control groups $(\mathrm{P}<0.05)$. For the first time, this study demonstrated beneficial effects of sildenafil on the breaking strength, as well as on histological properties of surgical wound healing of the abdominal fascia wall in an experimental model (4).

\section{Clinical use of sildenafil for wound healing in human studies}

\section{Effect of sildenafil on refractory skin ulceration in antiphospholipid syndrome}

Refractory skin ulcers are among the skin manifestations of antiphospholipid syndrome (8788 ). For many years, heparin and fibrinolytic agents were the only successful treatment for such ulcers (88). However, the risk of bleeding is a major complication of this intervention (88).

In 2003, a man was reported with non-healing cutaneous ulcers and a 10 year history of antiphospholipid syndrome.

\begin{tabular}{|c|c|c|c|c|}
\hline Study & Subjects/No. & Intervention & $\begin{array}{c}\text { Duration of sildenafil } \\
\text { therapy }\end{array}$ & Effects of sildenafil \\
\hline $\begin{array}{l}\text { Gertner } \\
(64)\end{array}$ & $\begin{array}{l}\text { Refractory skin ulceration in } \\
\text { antiphospholipid syndrome/ } \\
1^{*}\end{array}$ & $\begin{array}{l}\text { Fifty mg of sildenafil daily orally } \\
\text { without any other intervention }\end{array}$ & 18 months & $\begin{array}{l}\text { Significant reduction in pain was noticed } \\
\text { over few weeks and also, ulcers healed } \\
\text { completely within the next three months. No } \\
\text { recurrence of ulceration and pain and no side } \\
\text { effects were reported until } 18 \text { months. }\end{array}$ \\
\hline $\begin{array}{l}\text { Colglazier } \\
\text { et al. }(62)\end{array}$ & $\begin{array}{l}\text { Multiple non-healing fingertip } \\
\text { ulcerations in limited } \\
\text { cutaneous SS/1* }\end{array}$ & $\begin{array}{l}\text { Sildenafil was Initiated with dose of } \\
50 \mathrm{mg} \text { daily, then reduced to } 25 \mathrm{mg} \\
\text { daily and finally returned to } 50 \mathrm{mg} \\
\text { daily with other interventions }\end{array}$ & 4 months & His ulcers were healed completely \\
\hline $\begin{array}{l}\text { Gore et al. } \\
\text { (44) }\end{array}$ & $\begin{array}{l}\text { Refractory DUs to } \\
\text { conventional therapy } \\
\text { secondary to SS reviewed in } \\
\text { retrospective chart review } / 8\end{array}$ & $\begin{array}{l}\text { Sildenafil dose varied from } 12.5 \text { to } \\
100 \mathrm{mg} \text { daily }\end{array}$ & $\begin{array}{l}\text { Was not mentioned } \\
\text { clearly }\end{array}$ & $\begin{array}{l}\text { Six of eight patients experienced complete } \\
\text { healing of the ulcers }\end{array}$ \\
\hline $\begin{array}{l}\text { Wollina et } \\
\text { al. (65) }\end{array}$ & $\begin{array}{l}\text { chronic skin ulcers in } \\
\text { disabling panscleroticmorphea } \\
\text { of childhood (DPMC)/1* }\end{array}$ & $\begin{array}{l}\text { Combination treatment of sildenafil } \\
(20 \mathrm{mg} \text { three times daily) and } \\
\text { Oasis }{ }^{\circledR} \text { wound dressing } \phi\end{array}$ & 2 weeks & $\begin{array}{l}\text { wound improved with a significant better } \\
\text { granulation was noted, also repeated } \\
\text { application of this combination achieved a } \\
\text { marked improvement in healing of particular } \\
\text { severe type of scleroderma }\end{array}$ \\
\hline $\begin{array}{l}\text { Ambach et } \\
\text { al. (45) }\end{array}$ & $\begin{array}{l}\text { recurrent progressive painful } \\
\text { DUs in a woman with PSS/1* }\end{array}$ & $\begin{array}{l}\text { low-dose combination therapy of } \\
\text { sildenafil ( } 12.5 \mathrm{mg} \text { daily) and } \\
\text { bosentan ( } 125 \mathrm{mg} \text { daily) }\end{array}$ & 1 year & $\begin{array}{l}\text { low-dose combination therapy of sildenafil } \\
\text { and bosentan led to completely and rapidly } \\
\text { healing in about } 10 \text { years of therapy and } \\
\text { during one year follow-up no new ulcers } \\
\text { appeared }\end{array}$ \\
\hline $\begin{array}{l}\text { Brueckner } \\
\text { et al. (66) }\end{array}$ & $\begin{array}{l}\text { Refractory digital ulcers to } \\
\text { treatment in SS/19 }\end{array}$ & $\begin{array}{l}\text { Maximally tolerated sildenafil } \\
\text { doses (up to } 150 \mathrm{mg} \text { ) }\end{array}$ & maximum of 6 months & $\begin{array}{l}\text { A significant decrease in DUs was mentioned } \\
\text { at the end of sildenafil treatment }\end{array}$ \\
\hline $\begin{array}{l}\mathrm{Ng} \text { et al. } \\
(63)\end{array}$ & $\begin{array}{l}\text { ischemic ulceration in } \\
\text { fingertip related to primary } \\
\text { Raynaud's disease/1* }\end{array}$ & Sildenafil $50 \mathrm{mg}$ orally, once daily & 3 months & $\begin{array}{l}\text { pain and ischemic symptoms disappeared } \\
\text { within hours of first administration, but } \\
\text { symptoms were recurred within a few weeks } \\
\text { when discontinued of sildenafil }\end{array}$ \\
\hline $\begin{array}{l}\text { Moinzadeh } \\
\text { et al. (47) }\end{array}$ & $\begin{array}{l}\text { DUs in diffuse systemic } \\
\text { sclerosis } / 1^{*}\end{array}$ & $\begin{array}{l}\text { combination treatment with } \\
\text { Sildenafil ( } 60 \mathrm{mg} \text { daily) and } \\
\text { bosentan ( } 125 \mathrm{mg} \text { twice daily) }\end{array}$ & 6 months & $\begin{array}{l}\text { digital ulcers were healed completely under } \\
\text { this combination for the first time during his } \\
\text { medical history }\end{array}$ \\
\hline $\begin{array}{l}\text { Rossa et } \\
\text { al. (67) }\end{array}$ & DUs in $\mathrm{SS} / 5$ & $\begin{array}{l}\text { Sildenafil was started with the dose } \\
\text { of } 12.5-60 \mathrm{mg} \text {, final dose was } 25- \\
120 \mathrm{mg}\end{array}$ & $\begin{array}{l}16.2 \text { months }(4-48 \\
\text { months) }\end{array}$ & $\begin{array}{l}\text { A total of } 31 \text { from } 44(70.5 \%) \text { ulcerations } \\
\text { healed after sildenafil therapy }\end{array}$ \\
\hline
\end{tabular}


His past medical history revealed non-healing and extremely painful ulcers that were refractory to local wound care, corticosteroids, aspirin, and warfarin.Throughout course of the disease, the patient received heparin plus intravenous tissue plasminogen activator on 3 occasions over 5 years, which led to complete resolution of the ulcers, but the ulcers and pain recurred one year after each course of treatment. In 2000, non-healing ulcers with severe pain appeared again. Sildenafil at a dose of $50 \mathrm{mg} /$ daily orally was started for the patient, without any other intervention. A significant reduction in pain was detected over a few weeks and the ulcers healed completely within the next 3 months. Interestingly, no recurrence of ulceration and pain and no side effects were reported by the patient until 18 months later (64). The clinical studies that have evaluated the effects of sildenafil on the wound healing are summarized in Table 2.

\section{Effect of sildenafil on healing of ulcers in systemic sclerosis}

Systemic sclerosis (scleroderma) is a multisystem fibrotic disease with complications that include a different type of vasculopathy, digital ulcers, and pulmonary artery hypertension (89), which have a great impact on the quality of life of these patients (90). A role for vasoconstrictive factors such as endothelin was shown in the vasculopathy of this disease (91). Although an endothelin receptor blocker such as bosentan showed beneficial effects in the prevention of digital ulcers, it was not effective in the healing of the ulcers (92). Intravenous iloprost is another treatment option for ulcers, but it is not an effective preventive modality (93). Reduced levels of NO have been proposed as an additional contributing factor in the pathogenesis of systemic sclerosis induced vasculopathy (94). Based on these mechanisms of vasculopathy, a selective inhibitor of PDE type 5, such as sildenafil, remains an attractive option for the treatment of vascular disease in systemic sclerosis (95).

In 2005, a man who was a known case of limited cutaneous systemic sclerosis was referred with multiple non-healing fingertip ulcerations (62). $\mathrm{He}$ received nifedipine, aspirin, and pentoxyphylline for more than one month but his ulcers worsened. Sildenafil, at a dose of $50 \mathrm{mg}$ per day, was then initiated. Because of his hypotension symptoms, the sildenafil dose was reduced to $25 \mathrm{mg}$ daily and nifedipine was discontinued. After resolution of the hypotension symptoms, the sildenafil dose was returned to $50 \mathrm{mg}$ per day and was well tolerated. During this regimen, the patient experienced gradual healing of his digital ulcers and after 4 months of the treatment, his ulcers were healed completely (62).

Soon after, in 2005, in a retrospective chart review, data of 8 patients with refractory ulcers secondary to systemic sclerosis were reported (44). These patients received sildenafil (12.5 to $100 \mathrm{mg}$ daily) after unresponsiveness to standard treatment (calcium channel blockers, $\alpha$ blockers, angiotensin converting enzyme inhibitors, aspirin, dipyridamole, pentoxifylline, and/or topical nitrates). Six out of 8 patients with refractory digital ulcers improved completely after sildenafil therapy. This treatment well tolerated although one case experienced chest discomfort after taking sildenafil, which resulted in treatment discontinuation (44).

In the most recent study, another small series of 15 patients with systemic sclerosis were treated with sildenafil for their ulcers (67). In 5 patients, sildenafil was added to iloprost when it failed to heal the ulcers. In 2 patients, sildenafil was initiated for treatment of ulcers; however, patients also received bosentan for their pulmonary artery hypertension. The total number of ulcers in the patients was 44 at baseline evaluation. Sildenafil was started at a dose of 12.5-60 $\mathrm{mg}$ and was increased gradually. The final dose of sildenafil was 25-120 $\mathrm{mg}$, and the mean duration of therapy was 16.2 months (ranged from 4 to 48 months). A total of 31 out of the $44(70.5 \%)$ ulcers healed after sildenafil therapy and only one patient stopped sildenafil therapy due to lack of efficacy. Whereas 16 ulcers (from 5 patients) healed after a brief time of sildenafil therapy (1-3 months), 15 ulcers (from three patients) healed after a longer period (up to 24 months). This small study demonstrated that sildenafil alone or in combination with conventional therapy significantly improved the number of healed skin ulcers and patients did not experience any major side effects (67).

In 2010, the effect of sildenafil on ulcer healing was evaluated in 19 patients with systemic sclerosis (66). In this pilot study, maximum tolerable dose of sildenafil (up to $150 \mathrm{mg}$ ) was used for up to 6 months in patients with refractory ulcers. The patients had 3 month histories of vasoactive and immunosuppressive therapies. After addition of 
sildenafil, a significant decrease in ulcers was reported in these patients. The results suggested that sildenafil could be an effective therapeutic option for digital ulcer healing.

A progressive course of the disease is identified in $30 \%$ of the patients with systemic sclerosis. Painful and chronic distal ulcerations, which can lead to loss of limbs in spite of aggressive therapy, were reported in these patients (46). Although novel therapies such as prostaglandin or its analogues are available now, PDE 5 inhibitors such as sildenafil, and endothelin receptor antagonists such as bosentan, can be helpful in this setting (46). In 2009, Ambach et al. reported a woman with progressive systemic sclerosis who suffered from renal failure and recurrent progressive painful digital ulcers (45). The patient first received methylprednisolone, as well as vasodilators such as isosorbide dinitrate and nifedipine, followed by addition of pentoxyphylline and weekly iloprost infusion and ramipril due to the disease progression. After response failure or intolerance to other therapies such as azathioprine, iloprost, and photopheresis, a daily treatment of sildenafil (12.5 mg daily) was added. Due to exacerbation of the patient's ulcers, bosentan was started and iloprost and photopheresis were discontinued. This low dose of sildenafil, in combination with bosentan, resulted in complete and rapid healing of the patient's ulcers. During the 1 year follow-up, no new ulcers appeared. This report showed the beneficial effects and safety of combination of bosentan and sildenafil as a treatment for systemic sclerosis ulcers (45). In another case report in 2011, a man with diffuse systemic sclerosis and digital ulcers was also treated successfully with a combination of bosentan and sildenafil (47).

A non-English language case report in 2008 showed that oral administration of sildenafil was effective in a man suffering from progressive systemic sclerosis with acral ulcers; it induced a complete and long-lasting healing of all ulcers within 5 weeks. This case also suggested that sildenafil is an effective treatment for refractory scleroderma acral ulcers (96).

Sildenafil was successfully used in a patient with disabling pansclerotic morphea of childhood, who suffered from chronic skin ulcers (65). The case was a boy who had received cyclosporine, prednisolone, methotrexate, and D-penicillamine for disabling pansclerotic morphea of childhood, without any benefit. He demonstrated chronic foot ulcers which were treated with chlorhexidine, gentamicin ointment, and transcutaneous application of dry carbon dioxide gas to reduce colonization and improve granulation of the ulcers (97), but these treatments were not effective. Compression therapy resulted in a marked reduction in malodorous discharge from the wounds and improved granulation within 3 weeks, but no reepithelization was noted. Although minor improvement was achieved with a porcine acellular matrix skin substitute (Oasis ${ }^{\circledR}$ wound dressing), the wound improved significantly following 2 weeks treatment with sildenafil $(20 \mathrm{mg}$, three times in a day). Thus, the repeated application of sildenafil, in combination with a porcine small intestinal submucosal acellular matrix, as a treatment for chronic ulcers resulted in a marked improvement in the healing of a particularly severe type of scleroderma (65).

\section{Effect of sildenafil on healing of ulcers in primary Raynaud's disease}

Healing of ischemic ulcers, especially in patients with underlying vasospastic or collagen vascular disorders, remains a challenging issue. Surgical procedures, such as vascular bypass, sympathectomy, and often amputation, have traditionally been used to treat critically ischemic ulcers (98). PDE inhibitors such as sildenafil, by increasing the concentration of $\mathrm{NO}$ and maintaining peripheral blood flow, can also exert therapeutic benefits in the ulcers related to primary Raynaud's disease (63).

$\mathrm{Ng}$ et al. (63), in 2010 described a primary Raynaud's case with purple discoloration of the fingertip. Nifedipine, aspirin, and hydromorphone were selected as primary treatment options for this patient. However, the patient's symptoms were not relieved and ischemic ulceration also appeared in the fingertip. In spite of a marked improvement of the patient's symptoms following digital sympathectomy, the symptoms relapsed on postoperative day 10. The aspirin dose was then increased and nitropaste ointment $2 \%$ was applied topically twice daily on the fingertips to alleviate the symptoms. These interventions were effective and capillary filling was improved. However, one year after his initial presentation, all digits of both hands became affected and the nifedipine dose was increased and oral pentoxyphylline was added. 
Because his pain remained unchanged, sildenafil (50 mg orally, once daily) was started. The patient's pain and ischemic symptoms disappeared rapidly within a few hours following first dose of sildenafil. The patient remained symptom-free on sildenafil therapy for 3 months, but he experienced recurrence of symptoms within a few weeks when sildenafil was discontinued (63). These clinical observations support the beneficial effects of sildenafil in improvement of ulcers in peripheral vascular diseases.

\section{CONCLUSION}

A total of 15 animal studies, 7 case reports, and 2 small clinical studies have been evaluated to explore the effects of sildenafil on the wound healing. These data support the beneficial effects of sildenafil in improvement of tissue healing in various conditions ranging from skin flaps, skin grafts, and anastomosis to systemic sclerosis and Raynaud's disease. Most of the patients who were treated with sildenafil in clinical settings were refractory to previous treatments; however, no positive control groups were used in these studies to compare the beneficial effect of sildenafil with conventional or other treatment in wound healing. Well-designed controlled studies are, therefore, still needed to evaluate the effects of sildenafil alone or in combination with other therapeutic agents in different types of injuries.

Sildenafil may represent a rescue therapy in patients who are not responsive to conventional therapy in different settings, such as systemic sclerosis or Raynaud's phenomenon. Alternatively, it also may be the first choice in patients in whom other medications are contraindicated or difficult to access.

\section{Expert opinion and future perspective}

Sildenafil is a novel agent for treatment of ulcers, especially in systemic sclerosis related ulcers, due to its ease of administration and relatively acceptable side effect profile. To date, administration of sildenafil in vascular diseases is growing in general. Experience with sildenafil use in systemic sclerosis-related ulcers remains limited but is increasing. However, sildenafil is not effective in the treatment of the the underlying cause of scleroderma, although it may be useful to help healing of related ulcers and possibly postpone surgical intervention. Future clinical studies are needed to define effective and safe dose, route of administration and treatment duration of sildenafil for wound healing in human subjects.

\section{REFERENCES}

1. McDermott-Scales L, Cowman S, Gethin G. Prevalence of wounds in a community care setting in Ireland. Journal of wound care, 2009;18(10):405417.

2. Bours GJ HR, Abu-Saad HH, Grol RT. Prevalence, prevention, and treatment of pressure ulcers: descriptive study in 89 institutions in the Netherlands. Research in nursing \& health, 2002;25(2):99-110.

3. Tas A, Atasoy N, Ozbek H, Aslan L, Yuksel H, Ceylan E, et al. The effects of sildenafil citrate (Viagra) in the early phase of healing process in open wounds in dogs. Acta Vet Brno, 2003;72:273277.

4. Derici H KE, Unalp HR, Diniz G, Bozdag AD, Tansug T, Ortac R, Erbil Y. Effect of sildenafil on wound healing: an experimental study. Langenbecks Arch Surg, 2009:1-6.

5. Soneja A, Drews M, Malinski T. Role of nitric oxide, nitroxidative and oxidative stress in wound healing. Pharmacol Rep, 2005;57:108-119.

6. Martin P. Wound healing--aiming for perfect skin regeneration. Science, 1997;276(5309):75-81.

7. Ziche M, Morbidelli L. Nitric oxide and angiogenesis. J Neurooncol, 2000;50(1):139-148.

8. Chung AW RA, Alonso-Escolano D, Jurasz P, Stewart MW, Malinski T, Radomski MW. Plateletleukocyte aggregation induced by PAR agonists: regulation by nitric oxide and matrix metalloproteinases. $\quad \mathrm{Br} \quad \mathrm{J}$ pharmacol 2004;143(7):845-55.

9. Cooke JP, Losordo DW. Nitric oxide and angiogenesis. Circulation, 2002;105(18):2133-2135.

10. Schwentker A, Vodovotz Y, Weller R, Billiar TR. Nitric oxide and wound repair: role of cytokines? Nitric Oxide, 2002;7(1):1-10.

11. Stallmeyer B KH, Kolb N, Pfeilschifter J, Frank S. The function of nitric oxide in wound repair: inhibition of inducible nitric oxide-synthase severely impairs wound reepithelialization. $\mathrm{J}$ Invest Dermatol, 1999;113(6):1090-1098.

12. Nakamura H, Herzenberg LA, Bai J, Araya S, Kondo N, Nishinaka Y, et al. Circulating thioredoxin suppresses lipopolysaccharide-induced neutrophil chemotaxis. Proc Natl Acad Sci U S A, 2001;98(26):15143-15148.

13. Furchgott RF. The discovery of endothelium-derived relaxing factor and its importance in the 
identification of nitric oxide. JAMA, JAm Med Assoc, 1996;276(14):1186-1188.

14. Weller R, Schwentker A, Billiar TR, Vodovotz Y. Autologous nitric oxide protects mouse and human keratinocytes from ultraviolet $\mathrm{B}$ radiation-induced apoptosis. Am J Physiol cell Physiol, 2003;284(5):C1140-C1148.

15. Krischel V B-GD, Suschek C, Kröncke KD, Ruzicka T, Kolb-Bachofen V. Biphasic effect of exogenous nitric oxide on proliferation and differentiation in skin derived keratinocytes but not fibroblasts. J Invest Dermatol, 1998;111(2):286-291.

16. Stamler JS, Jia L, Eu JP, McMahon TJ, Demchenko IT, Bonaventura J, et al. Blood flow regulation by Snitrosohemoglobin in the physiological oxygen gradient. Science, 1997;276(5321):2034-2037.

17. Weller R, Ormerod AD, Hobson RP, Benjamin NJ. A randomized trial of acidified nitrite cream in the treatment of tinea pedis. J Am Acad Dermatol, 1998;38(4):559-563.

18. Weller R. Nitric oxide donors and the skin: useful therapeutic agents? Clin Sci (Lond), 2003;105(5):533-536.

19. Tucker A, Pearson R, Cooke E, Benjamin N. Effect of nitric-oxide-generating system on microcirculatory blood flow in skin of patients with severe Raynaud's syndrome: a randomised trial. The Lancet, 1999;354(9191):1670-1675.

20. Anderson M, Moore T, Hollis S, Jayson M, King T, Herrick A. Digital vascular response to topical glyceryl trinitrate, as measured by laser Doppler imaging, in primary Raynaud's phenomenon and systemic sclerosis. Rheumatology, 2002;41(3):324328.

21. Yamasaki K, Edington H, McClosky C, Tzeng E, Lizonova A, Kovesdi I, et al. Reversal of impaired wound repair in iNOS-deficient mice by topical adenoviral-mediated iNOS gene transfer. J Clin Invest, 1998;101(5):967-971.

22. Lee PC, Salyapongse AN, Bragdon GA, Shears LL, Watkins SC, Edington HDJ, et al. Impaired wound healing and angiogenesis in eNOS-deficient mice. Am J Physiol cell Physiol, 1999;277(4):H1600H1608.

23. Schaffer MR, Tantry U, Efron PA, Ahrendt GM, Thornton FJ, Barbul A. Diabetes-impaired healing and reduced wound nitric oxide synthesis: a possible pathophysiologic correlation. Surgery, 1997;121(5):513-519.

24. Stallmeyer B, Anhold M, Wetzler C, Kahlina K, Pfeilschifter J, Frank S. Regulation of eNOS in normal and diabetes-impaired skin repair: implications for tissue regeneration. Nitric Oxide, 2002;6(2):168-177.
25. Witte M, Kiyama T, Barbul A. Nitric oxide enhances experimental wound healing in diabetes. Br J Surg, 2002;89(12):1594-1601.

26. Witte MB, Thornton FJ, Tantry U, Barbul A. LArginine supplementation enhances diabetic wound healing: Involvement of the nitric oxide synthase and arginase pathways. Metabol, Clin Exp, 2002;51(10):1269-1273.

27. Webb DJ, Freestone S, Allen MJ, Muirhead GJ. Sildenafil citrate and blood-pressure-lowering drugs: results of drug interaction studies with an organic nitrate and a calcium antagonist. Am J Cardiol, 1999;83(5):21-28.

28. Boolell M, Gepi-Attee S, Gingell J, Allen M. Sildenafil, a novel effective oral therapy for male erectile dysfunction. Br J Urol, 1996;78(2):257-261.

29. Jackson G, Gillies H, Osterloh I. Past, present, and future: a 7-year update of Viagra (sildenafil citrate). Int J Clin Pract, 2005;59(6):680-691.

30. Basson R, McInnes R, Smith MD, Hodgson G, Koppiker N. Efficacy and safety of sildenafil citrate in women with sexual dysfunction associated with female sexual arousal disorder. J Womens Health Gend Based Med, 2002;11(4):367-377.

31. Laan E, Van Lunsen RHW, Everaerd W, Riley A, Scott E, Boolell M. The enhancement of vaginal vasocongestion by sildenafil in healthy premenopausal women. J Womens Health Gend Based Med, 2002;11(4):357-365.

32. Caruso S, Intelisano G, Lupo L, Agnello C. Premenopausal women affected by sexual arousal disorder treated with sildenafil: a double-blind, cross-over, placebo-controlled study. $\mathrm{Br} \mathrm{J}$ Obstet Gynaecol, 2001;108(6):623-628.

33. Zhang R, Wang Y, Zhang L, Zhang Z, Tsang W, Lu $M$, et al. Sildenafil (Viagra) induces neurogenesis and promotes functional recovery after stroke in rats. Stroke, 2002;33(11):2675-2680.

34. Zhang R, Wang L, Zhang L, Chen J, Zhu Z, Zhang $Z$, et al. Nitric oxide enhances angiogenesis via the synthesis of vascular endothelial growth factor and cGMP after stroke in the rat. Circulation research, 2003;92(3):308-313.

35. Das S, Maulik N, Das D, Kadowitz P, Bivalacqua T. Cardioprotection with sildenafil, a selective inhibitor of cyclic 3', 5'-monophosphate-specific phosphodiesterase 5. Drugs Exp Clin Res, 2002;28(6):213-219.

36. Salloum F, Yin C, Xi L, Kukreja RC. Sildenafil induces delayed preconditioning through inducible nitric oxide synthase-dependent pathway in mouse heart. Circ Res, 2003;92(6):595-597.

37. Sastry B, Narasimhan C, Reddy N, Anand B, Prakash G, Raghava Raju P, et al. A study of clinical efficacy of sildenafil in patients with primary 
pulmonary hypertension. Indian Heart J, 2002;54(4):410-414.

38. Sastry B, Narasimhan C, Reddy NK, Raju BS. Clinical efficacy of sildenafil in primary pulmonary hypertension:: A randomized, placebo-controlled, double-blind, crossover study. J Am Coll Cardiol, 2004;43(7):1149-1153.

39. Chen YJ, Traverse JH, Hou M, Li Y, Du R, Bache RJ. Effect of PDE5 inhibition on coronary hemodynamics in pacing-induced heart failure. Am J Physiol Heart Circ Physiol, 2003;284(5):H1513H1520.

40. Fischer T, Erbel R, Treese N. Current status of phosphodiesterase inhibitors in the treatment of congestive heart failure. Drugs, 1992;44(6):928-945.

41. Ulusoy MG, Uysal A, Ko Âßer U, Karaaslan Ã, Cuzdan SS, Ayyldz A, et al. Improved flap viability with site-specific delivery of sildenafil citrate using fibrin glue. Annals of plastic surgery, 2005;55(3):292.

42. Sarifakioglu N, Gokrem S, Ates L, Akbuga UB, Aslan G. The influence of sildenafil on random skin flap survival in rats: an experimental study. $\mathrm{Br} \mathrm{J}$ Plast Surg, 2004;57(8):769-772.

43. Li Z, Xi X, Gu M, Feil R, Ye RD, Eigenthaler M, et al. A stimulatory role for cGMP-dependent protein kinase in platelet activation. Cell, 2003;112(1):7786.

44. Gore J, Silver R. Oral sildenafil for the treatment of Raynaud's phenomenon and digital ulcers secondary to systemic sclerosis. Ann Rheum Dis, 2005;64(9):1387.

45. Ambach A, Seo W, Bonnekoh B, Gollnick H. Lowdose combination therapy of severe digital ulcers in diffuse progressive systemic sclerosis with the endothelin-1 receptor antagonist bosentan and the phosphodiesterase $\mathrm{V}$ inhibitor sildenafil. JDDG, 2009;7(10):888-891.

46. Chung L. Therapeutic options for digital ulcers in patients with systemic sclerosis. J Dtsch Dermatol Ges, 2007;5(6):460-465.

47. Moinzadeh P, Hunzelmann N, Krieg T. Combination therapy with an endothelin-1 receptor antagonist (bosentan) and a phosphodiesterase $\mathrm{V}$ inhibitor (sildenafil) for the management of severe digital ulcerations in systemic sclerosis. J Am Acad Dermatol, 2011;65(3):102-104.

48. Austin MJ, McDougall NI, Wendon JA, Sizer E, Knisely AS, Rela M, et al. Safety and efficacy of combined use of sildenafil, bosentan, and iloprost before and after liver transplantation in severe portopulmonary hypertension. Liver Transpl, 2008;14(3):287-291.

49. Catapano-Minotti G, Corsonello A, Guadalupi G, Spani R, Antonelli-Incalzi R. Treatment of severe pulmonary hypertension secondary to scleroderma: a three-drug approach. Intern Med, 2008;47(6):511.

50. Ayyildiz A UA, Koçer U, Karaaslan O, Huri E, Germiyanoglu C, Caydere M. Effect of sildenafil citrate on viability of flaps: an experimental study in rats. Scand J Plast Reconstr Surg Hand Surg, 2005;39(4):204-208.

51. Hart K BD, Hodam J, Lesoon-Wood L, Parham M, Keith K, Vazquez R, Ager E, Pizarro J. Short- and long-term effects of sildenafil on skin flap survival in rats. Laryngoscope, 2006;116(4):522-528.

52. Konstantinos G, Petros P. Phosphodiesterase-5 inhibitors: future perspectives. Current pharmaceutical design, 2009;15(30):3540-3551.

53. Tsai JW, Ayubi FS, Hart KL, Baur DA, Parham MA, Moon JK, et al. Evaluation of the effect of sildenafil and vascular endothelium growth factor combination treatment on skin flap survival in rats. Aesthetic Plast Surg, 2008;32(4):624-631.

54. Ayyildiz A, Akgul K, Nuhoglu B, Huri E, Caydere M, Ustun H, et al. An Experimental study: Does topically applied sildenafil citrate (Sildegra ${ }^{\circledR}$ ) have an effect on the preservation of the viability of the graft in full-thickness tubed free skin grafts? . Turk J Med Sci, 2006;36(6):343-348.

55. Irkorucu O TO, Cakmak GK, Karakaya K, Emre AU, Ucan BH, Bahadir B, Acikgoz S, Ankarali H, Ugurbas E, Comert M. The effect of sildenafil on an animal model for ischemic colitis. Dig Dis Sci, 2008;53(6):1618-1623.

56. Batukan C, Ozgun MT, Basbug M, Muderris II. Sildenafil reduces postoperative adhesion formation in a rat uterine horn model. Eur J Obstet Gynecol Reprod Biol, 2007;135(2):183-187.

57. Irkorucu O, Ucan BH, Cakmak GK, Emre AU, Tascilar O, Ofluoglu E, et al. Does sildenafil reverse the adverse effects of ischemia on ischemic colon anastomosis: yes, 'no'. Int J Surg, 2009;7(1):39-43.

58. Uzun H KD, Nuri MK, Ersoy EY, Ozçevik S, Yavuz $\mathrm{N}$. The effects of sildenafil citrate on ischemic colonic anastomotic healing in rats: its relationship between nitric oxide and oxidative stress. World $\mathbf{J}$ Surg, 2008;32(9):2107-2113.

59. Barral SM, Araujo ID, Vidigal PVT, Mayrink CAC, Araujo AD, Costa PR. Effects of sildenafil on the viability of random skin flaps. Acta Cir Bras, 2011;26(4):314-319.

60. Ayten R CZ, Girgin M, Ozercan I, Ustundag B, Aygen E. The effects of intraperitoneal sildenafil administration on healing of left colonic anastomoses and intra-abdominal adhesion formation in the presence of intra-abdominal infection. Dis Colon Rectum, 2008;51(12):18371841. 
61. Jamshidzadeh A, Azarpira N. The Effects of Topical Sildenafil on Wound Healing in Rat. Iranian Journal of Pharmaceutical Sciences, 2010;7(1):43-48.

62. Colglazier CL, Sutej PG, O'Rourke KS. Severe refractory fingertip ulcerations in a patient with scleroderma: successful treatment with sildenafil. The Journal of rheumatology, 2005;32(12):24402442.

63. Ng WK RY, Brock GB, O'Gorman DB, Siang Gan B. Phosphodiesterase inhibitors in vascular ischemia: A case report and review of their use in ischemic conditions. Can J Plast Surg, 2010;18(1):e5-e9.

64. Gertner E. Treatment with sildenafil for the healing of refractory skin ulcerations in the antiphospholipid syndrome. Lupus, 2003;12(2):133-135.

65. Wollina U BM, Heinig B, Petrov I, Unger E, Kyriopoulou E, Koch A, Köstler E, Schönlebe J, Haroske G, Doede T, Pramatarov K. Disabling pansclerotic morphea of childhood poses a high risk of chronic ulceration of the skin and squamous cell carcinoma. Int $\mathrm{J}$ Low Extrem Wounds, 2007;6(4):291-298.

66. Brueckner CS, Becker MO, Kroencke T, Huscher D, Scherer HU, Worm M, et al. Effect of sildenafil on digital ulcers in systemic sclerosis: analysis from a single centre pilot study. Ann Rheum Dis, 2010;69(8):1475-1478.

67. Rossa AD, Doveri M, D'Ascanio A, Tavoni A, Consensi A, Neri R, et al. Oral sildenafil in skin ulcers secondary to systemic sclerosis. Scand J Rheumatol, 2011;40(4):323-325.

68. Vural E, Key JM. Complications, salvage, and enhancement of local flaps in facial reconstruction. Otolaryngol Clin North Am, 2001;34(4):739-751.

69. Slate RK, Ryan M, Bongard FS. Dependence of tissue oxygen on oxygen delivery. J Surg Res, 1996;61(1):201-205.

70. Tüz M EE, Doğru H, Delibaş N, Tunç B, Uygur K. The effect of replacement fluids and normovolaemic haemodilution on the survival of dorsal skin flaps in rats. Clin Otolaryngol Allied Sci, 2004;29(1):80-83.

71. Ergün H CM, Apaydin I, Erçöçen AR, Tulunay FC. The effect of dipyrone on survival of skin flaps. Scand J Plast Reconstr Surg Hand Surg, 2001;35(1):19-22.

72. Davis RE, Wachholz JH, Jassir D, Perlyn CA, Agrama MH. Comparison of topical anti-ischemic agents in the salvage of failing random-pattern skin flaps in rats. Facial Plast Surg, 1999;1(1):27-32.

73. Kerrigan CL, Daniel RK. Pharmacologic treatment of the failing skin flap. Plast Reconstr Surg, 1982;70(5):541-549.

74. Akgün A KS, Uraldi C, Tekin O, Karip B, Tug T, Ongören AU. Early effects of fibrin sealant on colonic anastomosis in rats: an experimental and case-control study. Tech Coloproctol, 2006;10(3):208-214.

75. NasirKhan MU, Abir F, Longo W, Kozol R. Anastomotic disruption after large bowel resection. World J Gastroenterol, 2006;12(16):2497-2504.

76. Angel MF, Ramasastry SS, Swartz WM, Narayanan $\mathrm{K}$, Kuhns DB, Basford $\mathrm{R}$, et al. The critical relationship between free radicals and degrees of ischemia: evidence for tissue intolerance of marginal perfusion. Plast Reconstr Surg, 1988;81(2):233-239.

77. Chiu CJ, McArdle AH, Brown R, Scott HJ, Gurd FN. Intestinal mucosal lesion in low-flow states: I. A morphological, hemodynamic, and metabolic reappraisal. Arch Surg, 1970;101(4):478-483.

78. Nair SK, Bhat IK, Aurora AL. Role of proteolytic enzyme in the prevention of postoperative intraperitoneal adhesions. Arch Surg, 1974;108(6):849-853.

79. Leach RE, Burns JW, Dawe EJ, SmithBarbour MD, Diamond MP. Reduction of postsurgical adhesion formation in the rabbit uterine horn model with use of hyaluronate/carboxymethylcellulose gel. Fertil Steril, 1998;69(3):415-418.

80. Knightly J, Agostino D, Cliffton E. The effect of fibrinolysin and heparin on the formation of peritoneal adhesions. Surgery, 1962;52:250-258.

81. Woessner J. The determination of hydroxyproline in tissue and protein samples containing small proportions of this imino acid. Arch Biochem Biophys, 1961;93(2):440-447.

82. Ehrlich HP, Tarver H, Hunt TK. Effects of vitamin $A$ and glucocorticoids upon inflammation and collagen synthesis. Ann Surg, 1973;177(2):222-227.

83. Li H, Fu X, Zhang L, Huang Q, Wu Z, Sun T. Research of PDGF-BB gel on the wound healing of diabetic rats and its pharmacodynamics. J Surg Res, 2008;145(1):41-48.

84. Qiu Z, Kwon A, Kamiyama Y. Effects of plasma fibronectin on the healing of full-thickness skin wounds in streptozotocin-induced diabetic rats. J Surg Res, 2007;138(1):64-70.

85. Gulcelik MA, Dinc S, Dinc M, Yenidogan E, Ustun $\mathrm{H}$, Renda N, et al. Local granulocyte-macrophage colony-stimulating factor improves incisional wound healing in adriamycin-treated rats. Surg Today, 2006;36(1):47-51.

86. Abramov Y, Golden B, Sullivan M, Botros SM, Miller JJR, Alshahrour A, et al. Histologic characterization of vaginal vs. abdominal surgical wound healing in a rabbit model. Wound Repair Regen, 2007;15(1):80-86.

87. Gibson GE, Daniel Su W, Pittelkow MR. Antiphospholipid syndrome and the skin. J Am Acad Dermatol, 1997;36(6):970-982.

88. Gertner E, Lie J. Systemic therapy with fibrinolytic agents and heparin for recalcitrant nonhealing 
cutaneous ulcer in the antiphospholipid syndrome. $\mathbf{J}$ Rheumatol, 1994;21(11):2159.

89. Furst DE. Rational therapy in the treatment of systemic sclerosis. Curr Opin Rheumatol, 2000;12(6):540-544.

90. Sunderkötter C, Riemekasten G. Pathophysiology and clinical consequences of Raynaud's phenomenon related to systemic sclerosis. Rheumatology, 2006;45(suppl 3):iii33-35.

91. Abraham D, Distler O. How does endothelial cell injury start? The role of endothelin in systemic sclerosis. Arthritis Res Ther, 2007;9(2):2.

92. Korn J, Mayes M, Matucci Cerinic M, Rainisio M, Pope J, Hachulla E, et al. Digital ulcers in systemic sclerosis: prevention by treatment with bosentan, an oral endothelin receptor antagonist. Arthritis Rheum, 2004;50(12):3985-3993.

93. Kawald A BG, Huscher D, Sunderkötter C, Riemekasten G. Low versus high-dose iloprost therapy over 21 days in patients with secondary Raynaud's phenomenon and systemic sclerosis: a randomized, open, single-center study. J Rheumatol, 2008;35(9):1830-1837.
94. Matucci Cerinic M, Kahaleh M. Beauty and the Beast. The nitric oxide paradox in systemic sclerosis. Rheumatology, 2002;41(8):843-847.

95. Freedman RR, Girgis R, Mayes MD. Acute effect of nitric oxide on Raynaud's phenomenon in scleroderma. The Lancet, 1999;354(9180):739.

96. Friedrichson E, Rehberger P, Fuhrmann J, Walz F, Meurer M, Pfeiffer C. [Fast and efficient healing of scleroderma-associated acral ulcers with sildenafil]. Hautarzt, 2008;59(3):230-232.

97. Wollina U, Heinig B, Uhlemann C. Transdermal $\mathrm{CO} 2$ application in chronic wounds. Int $\mathrm{J}$ Lower Extremity Wounds, 2004;3(2):103-106.

98. McLafferty RB, Edwards JM, Taylor LM, Porter JM. Diagnosis and long-term clinical outcome in patients diagnosed with hand ischemia. J Vasc Surg, 1995;22(4):361-369. 